reaching consensus on volatile issues was frequent; that public policy issues are simple. We were reassured that even these complaints demonstrated valuable lessons learned.

Responses to the open-ended questions confirmed our observation that most students were interested and motivated by the experience. A student in the Public Policy class wrote: "I felt like I was watching C-SPAN so this simulation must have been authentic. Perhaps I was too hard on the Congress class. They surprised me by just how much they knew about procedure. They conducted themselves like the important policy makers they were emulating." Another student maintained: "The simulation, I believe, was surprisingly successful. I had not anticipated that people would have become so involved early in the process. ... I was also surprised that the simulation was so realistic, based on what I had learned in class and, in large part, from Price's book [The Congressional Experience]. I had assumed that there would be superficial legislation passed and weak attempts at humor throughout the simulation. The bills submitted and passed were basically valid and timely, and the comedians few."

Role-playing simulations are useful instructional devices which can give students a more direct experience with course material. The macro-simulation combining three distinct classes provides an inter- esting alternative teaching method for political science undergraduates. Students, as well as instructors, must be willing to invest time and make advance preparations for participation in a macro-simulation. But the results can be rewarding.

\section{Notes}

The authors express their gratitude for assistance, support, and resources provided by the University of Missouri Alumni Association, the College of Arts and Science, the Department of Political Science, and Donna Hanly.

1. Care must be taken in the selection of the roles because students tend to uncharacteristically choose public interest organizations over more traditional lobbies. Competing interests (the NRA and Handgun Control, prolife and prochoice lobbies) significantly add to realism.

2. Once the simulation began, the instructors were reluctant to interfere in the decision-making process and restrict activity to the three policy areas. After preparation of research papers, however, most students naturally stayed within these confines and offered few bills or amendments outside the areas of environment, health, and technology.

3. Some students were initially impressed by the large number of people attending the introductory meeting. Seeing nearly a hundred other students from other classes seemed to instill feelings that this class project was important.

4. The paper, Simulation Weekly, had four editions and a post-simulation "extra" listing final outcomes of proposed legislation.

5. About $40-50 \%$ of a student's course grade depended on simulation-related activity. In the Interest Groups class, for instance, $20 \%$ of a student's grade came from the research paper (which served as the basis for that student's role), $20 \%$ from simulation participation (activities outside the classroom), and $10 \%$ from class participation (a portion of which dealt with the simulation).
6. The absence of fiscal constraints, for example, led the instructors to insist on funding limitations. Each bill had to fund itself (through specific budget cuts and so forth). But even this was done indirectly. The OMB and the White House issued electronic press releases, and a simulated President Clinton was quoted in Simulation Weekly as saying that he would veto any House legislation that raised taxes or the deficit.

7. One student did initially object to opening daily House sessions with a prayer but was satisfied when assured that this is a regular practice. The instructors were puzzled by the Representatives' refusal to leave their seats on the floor of the chamber even during one-minute speeches and legislative debate on predetermined votes. This curious phenomenon severely restricted lobbyists and staffers from contact with members of Congress as they were not allowed on the floor. On the other hand, members voluntarily met congressional norms. For instance, former President Richard Nixon died on the weekend of our simulation. Republicans wore black corsages after the announcement, and the House held a moment of silence during the Saturday session.

8. Four of these bills passed the Senate. A few bills were defeated in the House or failed to reach a floor vote. Most legislation, however, died in committee.

\section{About the Authors \\ James W. Endersby is an assistant professor of political science at the University of Mis- souri-Columbia. His publications include many articles on interest groups, political participation, and the legislative process.}

David J. Webber is an associate professor of political science at the University of Missouri-Columbia. He served as a APSA Congressional Fellow during 1992-93 and his research interests include public policy, biotechnology policy, and the use of policy information in the policy-making process.

\title{
The Quote Analysis: Teaching Political Science Students to Read with Focus
}

\author{
Charles Hersch, Cleveland State University
}

How often have we questioned our students about a book or article they have read, only to find that they cannot state the main arguments or even say what they have found interesting? Our first assump- tion might be that they have not done the reading, but frequently this turns out not to be the case. Instead, the problem lies with how they have read. Too often, when confronted with a reading assign- ment, students let their eyes run over the page line after line without having a clear sense of what is important or how it might relate to their lives. This is especially true in political theory courses, where stu- 
dents are confronted with "old," often difficult, texts written in a style to which they are unaccustomed.

I have devised an assignment called a "quote analysis" that helps students to read and write in a more focused and engaged manner. The instructions, contained in the syllabus, are as follows:

A quote analysis is a two-paragraph assignment in which you choose a quotation of no more than three sentences from the reading and discuss it. (The choice of quotation is entirely up to you, but pick a quote related to politics and the themes of the course.) In the first paragraph of the analysis explain the argument of the quote, in your own words. In the second paragraph present a reasoned argument of your own supporting, extending, or criticizing the thesis of the quotation.

I assign one every other week, although they can be used more or less frequently.

This assignment accomplishes a number of objectives. It teaches students that with some effort they can find something interesting even in difficult works. This may seem obvious to academics, but it is not to students reading primarily to fulfill the assignment and pass the course. The quote analysis helps make reading a process of active engagement rather than passive absorption. In addition, the quote analysis gets students to search for the argument while reading. This may take them a while to learn; they might focus on a trivial detail in the quotation. However, by the end of the term, most hone in on key arguments in the reading.

The quote analysis also teaches students to make stronger arguments themselves. Being asked both to state accurately the argument and to respond with their own view helps them learn that a strong argument against a particular point of view must be grounded in an accurate understanding of it. In my comments on their analyses, I point out ways to strengthen their argument: for example, by anticipating and answering possible objections, or by phrasing their view in a more limited and accurate manner. The assignment's two paragraph structure teaches students to develop a single argument. My comments often run something like, "You began by focusing on one argument, and then veered off in another direction. Pick one argument and develop it fully." They learn from this that a quotation, article, or book presents a series of interrelated points, and it is up to the writer to focus on one, omitting discussion of the others. As such, the quote analysis is a rehearsal for writing a paper with a single, fully developed thesis. Indeed, my paper assignments mirror the structure of the quote analysis: I tell them to devote two-thirds of the paper to a focused analysis of the writer's views and one third to their own argument in response.

The quote analysis can also be used to enhance class discussion by asking students to read their work aloud. Sharing with the class gives students a sense of mastery: they have something to teach others about political science. Students often are surprised at the insights their peers discover. One can also ask other students to respond to the presentation, or to present a counterargument.

One can structure these oral presentations in a number of ways. Sometimes I will ask several students the location of their quotations and ask them to present them in the order they occur in the text. This becomes a way of reading through the text in class. Sometimes we find that more than one student has picked the same quote and emphasized a different facet of what is being said; when this situation arises, students realize the possibility of differing interpretations of a work.

Alternatively, I have asked a student to present his or her analysis, and afterward asked, "Did anyone discuss a quote on a similar theme?" This thematic approach brings out a number of facets of a single theme within a work. However, it can also illustrate the relationship between the themes in a work: often a student will respond to one presentation with another about a different theme that seems to elaborate on or speak to the first.

Of course, focusing class discussion on quotations chosen by students does not guarantee that every important point in a text will be covered. However, in my experience most of the key arguments come to light. Points not encompassed by students can be discussed by the instructor at the end of the class or at the beginning of the next one.

Neither does quote analysis ensure that students will read the whole assignment. Some students read just enough to find a good quote. However, they soon learn that although they can minimally fulfill the assignment this way, they will not do well. It is difficult to write a good analysis of a single quote without having understood the larger structure of the argument contained in the rest of the assignment.

The quote analysis does not in itself accomplish the task of making students better readers and writers. It is primarily a supplement to the work done in class: reading texts together, finding the argument, and discussing its importance. As such a supplement, however, I have found it particularly valuable.

\footnotetext{
About the Author

Charles Hersch is assistant professor of political science at Cleveland State University. He has published articles about the political functions of the arts and American constitutional interpretation in Polity, Cultural Critique, and Legal Studies Forum. He is currently working on a book about the arts' role in political education in the United States in the 1950 s and 1960 s.
} 